\title{
化学構造からの有害性発現予測：人工知能技術の適用
}

\author{
植沢芳広
}

\section{AI-based QSAR Modeling for Prediction of Active Compounds in MIE/AOP}

\author{
Yoshihiro Uesawa \\ Department of Medical Molecular Informatics, Meiji Pharmaceutical University; \\ 2-522-1 Noshio, Kiyose, Tokyo 204-8588, Japan.
}

(Received August 1, 2019)

\begin{abstract}
Toxicity testing is critical for new drug and chemical development process. A clinical study, experimental animal models, and in vitro study are performed to evaluate the safety of a new drug. The limitations of these methods include extensive time for toxicity testing, an ethical problem, and high costs of experimentation. Therefore computational methods are considered useful for estimating chemical toxicity. In silico toxicity prediction is one of the toxicity assessments that uses computational methods to predict and stimulate the toxicity of chemicals. In silico study aims to contribute to effective development of new drug and chemical design. In this study, quantitative structure-activity relationship (QSAR) models will be used to predict toxicities based on chemical structural parameters. Because toxicities are complicated physiological phenomena, a similar toxicity expression might cause a different pathway. Also, since many drugs with unknown mechanisms of actions are available, the application of artificial intelligence (AI) - which uses sophisticated algorithms - is increasingly used to predict toxicities. Recently, the QSAR model was applied to determine complex relations between chemical structures and toxicities. However, accuracy of QSAR for toxicity prediction remains an important issue. International competitions funded by public institutions can address this issue. Two important toxicity challenges were organized in the past decade; this article presents issues of toxicity based on these challenges.
\end{abstract}

Key words_ artificial intelligence; adverse effect database; chemical structure; adverse outcome pathway; quantitative structure-activity relationship; machine learning

\section{はじめに}

新規な医薬品, 化学品の開発において, 機能とと もに安全性の評価は重要な項目である。新規物質の 有害性を評価するために，動物実験，in vitro 試験 等が実施されている。これらの手法は経済的，時間 的, 倫理的な制約を伴うことが多い. 一方, in sili$c o$ 毒性予測手法は, 上述した「wetな」試験法と比 較して極めてハイスループット性が高いため, 開発 早期に組み込むことにより新規物質の効率的な開発 に寄与し得る。本稿では化学構造から得られる情報 を用いて，構造のパターンから毒性を予測する in silico 手法である定量的構造活性相関（quantitative structure-activity relationship; QSAR) 解析関連手

明治薬科大学医療分子解析学研究室（T204-8588 東京 都清瀬市野塩 2-522-1)

e-mail: uesawa@my-pharm.ac.jp

本総説は, 日本薬学会第 139 年会シンポジウムS52 で 発表した内容を中心に記述したものである.
法を紹介する，一般に，毒性は複雑な生理現象であ ることが多い，類似した毒性表現型であっても原因 物質によって異なった生化学ルートで発現すること があり，その発現機序も未知の場合が少なくない.

このような特徴を有する毒性を予測のターゲットと する場合，化学構造と毒性の間の非線形で複雑な関 係をモデル化するために人工知能技術を適用する事 例が増えている，それでは，この先端技術を使用す ることによってどの程度の予測精度が達成されるの だろうか？この疑問に対して誤謬のない解答を得 るためには，公的な機関が実施した国際的なコンペ ティションの成果が参考となる。この十年以内に国 際的で大規模な毒性予測コンペティションが 2 回開 催されている。 2009 年に開催された Case Studies on the Development and Application of in-Silico Techniques for Environmental Hazard and Risk Assessment (CADASTER) Environmental Toxicity Challenge $^{1)}$ では，水生毒性としてテトラヒメナの 
成長阻害濃度を，2014 年に開催された National Institute of Health (NIH) Toxicology in the 21st Century (Tox21) Data Challenge 20142) では，有害性発現 経路（adverse outcome pathway; AOP）における初 期反応である分子開始イベント (molecular initiating event; MIE) を各々ターゲットとして，化学構 造式からこれらの毒性関連生理活性の予測を競うコ ンペティションであった。本稿では，両大会で入賞 した筆者の経験と QSAR 毒性予測の現状を紹介す るとともに，AOP の概念を QSAR 毒性予測に組み 入れた予測システムの概要を説明する.

\section{1. 定量的構造活性相関}

1964 年, ハンシュ教授と藤田博士は, 化学構造 上の特徵に依存する物理化学的性質と酵素活性の相

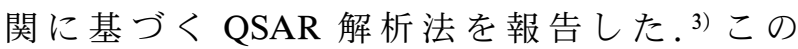
Hansh-Fujita 法は化学構造と生理活性の関係を定 量的に扱う種々手法の起点となっている.

QSAR 解析は酵素反応等の自由エネルギー差 を，物性によって説明するための手法であり，線形 重回帰分析等を用いることによって説明性を担保す ることが重要となる。一方，本稿において対象とす る毒性・有害性はかならずしも単一の重要なタンパ ク質の活性のみで説明できるとは限らない複雑な生 理現象である場合が多い。近年，このような複雑な 現象をターゲットとして QSAR 解析と類似した構 造情報との関係のモデル化に成功したとする論文が 多数報告されるようになり，これらの数理モデルを QSAR 予測モデルと称することが一般化しつつあ る. 4-7) なお，毒性をターゲットとした QSAR 様解 析法のことを定量的構造毒性相関（quantitative structure-toxicity relationship；QSTR）と表現する こともある，以下，QSTR の概念を含む“広義の QSAR”について述べる.

化学物質の引き起こす複雑な生理現象の 1 つとし て, 多細胞生物の増殖阻害が挙げられる．個体の増 殖は毒性物質によって異なる複雑なメカニズムを介 して抑制されると考えられることから，多様な化合 物群が惹起する増殖阻害に対して単一の原因タンパ ク質は想定し難い.にもかかわらず，化学物質が惹 起する死をターゲットとした予測を QSAR 解析に よって達成したとする, 魚類, ミジンコ, テトラヒ メナ等を対象とした解析事例が数多く存在す

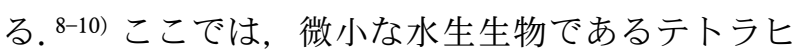

メナの増殖抑制活性を対象とした解析事例を紹介す る.

\section{CADASTER 環境毒性コンペティション}

欧州における環境リスク評価のためのインシリコ 技術開発研究プロジェクト CADASTER ${ }^{11)}$ が，人 工ニューラルネットワーク国際会議 2009 （International Conference on Artificial Neural Networks 2009；ICANN '09）及び欧州ニューラルネットワー ク協会 (European Neural Network Society; ENNS) と共催することにより，当時としては最大規模の環 境毒性 QSAR 予測コンペティションが開催され た。予測のエンドポイントはテトラヒメナに対する 化学物質の $50 \%$ 増殖抑制濃度（ICG50 值）であつ た。コンペティション参加者は主催者側より 644 種 類の QSAR モデル構築用化合物群及び 449 種類の モデル検証用化合物群の化学構造及び ICG50 值を 与えられた。一定期間後， ICG50 值を伏せられた 120 種類のブラインドテストセット化合物群におい て化学構造のみが開示された．参加者はモデル構築 用化合物セットから構築した QSAR モデルを用い て予測したブラインドテストセット化合物群の ICG50 值を主催者側に送り，主催者側は ICG50 実 測值と予測值の残差である二乗平均平方根誤差 （RMSE）を計算することによってモデルの精度を 決定した。なお，本コンペティションの詳細は CADASTER プロジェクトのホームページ (http:// www.cadaster.eu/node/65.html）を参照されたい. 上記の化合物構造等もホームページからダウンロー ドできる状態で保持されている.

CADASTER 環境毒性コンペティションの優勝者 は Dr. Gavin C. Cawley (University of East Anglia) 及び Dr. Olga Obrezanova (Optibrium Ltd.) の 2 チームとなった。 RMSE 值は各々 0.741 及び 0.756 であった．筆者も本コンペティションに参加し，第 9 位の成績であった（RMSE: 0.794）。なお，第 10 位までのチームの予測モデルは優勝者との間に統計

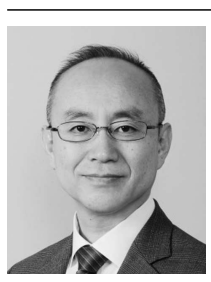

植沢芳広
明治薬科大学医療分子解析学研究室・ 教授. 京都大学薬学研究科博士課程修 了. 毒性予測コンペティションである NIH-Tox21 DATA Challenge 等にて入 賞. 医薬品・化学品の生理作用を理解 するために計算機化学的なアプローチ を試みている。 

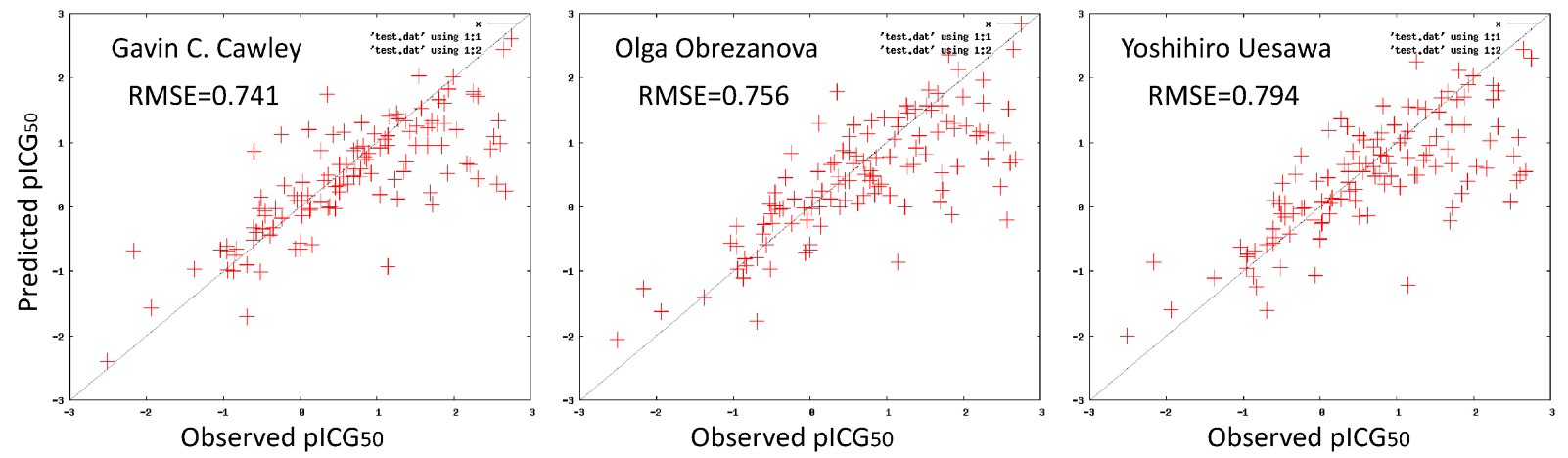

Fig. 1. Scatter Plots of Observed and Predicted pICG50 Values for the Final Evaluation Set Compounds in the CADASTER Environmental Toxicity Prediction Challenge

Extracted from http://www.cadaster.eu/sites/cadaster.eu/files/final_results.html (Color figure can be accessed in the online version.)

的有意差を示さないことが主催者側からコメントさ れ，われわれは first-pass winner と称された. Firstpass winner の予測モデル構築法にはサポートベク ターマシン等の機械学習法が多く見受けられ, 増殖 阻害活性のような複雑な生理活性を化学構造情報に 紐付けるには非線形手法が有用であることが推察さ れた．筆者が用いた方法も機械学習であるアンサン ブル人工ニューラルネットワークであった. Figure 1 に優勝者である Cawley 博士及び Obrezanova 博 士と第 9 位の筆者の予測結果を示す。前述したホー ムページから他の first-pass winner の予測結果も概 観できるが，すべてのモデルで同じ予測傾向を示し ていることが分かる，すなわち，多くのブラインド テストセット化合物において，誤差はあるものの QSAR 予測は可能である。一方，優勝者及び firstpass winner 全員の傾向として，一部の化合物群の 予測結果が過小評価されてしまっている。これらの 誤差は，モデル構築用化合物群の情報が不十分で あったことに起因している可能性が推察される.す なわち, QSAR 予測モデルの構築において, デー タセットの質と量が重要であることが示唆されてい ると考えられる.

3. 核内受容体・ストレス応答パスウェイ活性予 測コンペティション

2014 年, 核内受容体及びストレス応答パスウェ イを活性化する化合物の QSAR 解析技術を用いた 予測精度を競うコンペティションである Tox21 Data Challenge 2014 が開催された。 Tox21は，ア メリカの公的研究機関であるアメリカ国立衛生研究 所 (NIH)，アメリカ合衆国環境保護庁 (United States Environmental Protection Agency; U.S.
EPA)，及びアメリカ食品医薬品局（U.S. Food and Drug Administration; FDA）が参画する大規模な毒 性研究関連プロジェクトである。Tox21 Data Challenge 2014 は NIH の一機関である国立先進卜 ランスレーショナル科学センター（National Center for Advancing Translational Sciences; NCATS) が 開催した. ${ }^{12)}$ 本コンペティションでは，12 種類の主 要な AOP の MIE となり得る核内受容体及びス卜 レス応答パスウェイ ${ }^{13)}$ を活性化する化合物の識別が 課題とされた。参加者には 12 種類のターゲット （エストロゲン受容体 $\alpha$ ，エストロゲン受容体 $\alpha$ 基 質結合部位，アロマターゼ，AhR，アンドロゲン 受容体, アンドロゲン受容体基質結合部位, PPAR- $\gamma$, Nrf2/ARE，熱ショック応答エレメント, ATAD5, ミトコンドリア膜電位，及び p53）毎に 7000-9000 種類の化合物の化学構造及び活性化の有 無からなる情報が開示された。 上述の環境毒性予測 チャレンジを大きく上回る化合物に対する均質な実 験值が投入されているという意味において，これは 毒性関連の QSAR コンペティションとして史上最 大のスケールであった. 参加者の構築した予測モデ ルは活性を伏せられた 647 種類の最終評価用化合物 に対する予測結果に基づいて, receiver operating characteristic (ROC) 曲線下面積 (area under the curve；AUC）により評価された. 18 力国 125 チー ムが登録した本コンペティションにおける予測ター ゲット毎の優勝者の所属は Johannes Kepler University Linz, Technical University of Munich, Budapest University of Technology and Economics 及び明治薬 科大学（筆者の所属機関）となつた. ${ }^{14-16)}$ 優勝者は 全員が機械学習を使用しており，12 ターゲットに 
Table 1. Molecular Initiating Events Published in PubChem Database by Tox21 Project

\begin{tabular}{|c|c|c|c|}
\hline \# & AID & Molecular initiating events & Activity \\
\hline 1 & 1159528 & activator protein-1 & agonist \\
\hline 2 & 743054 & androgen receptor full & antagonist \\
\hline 3 & 743053 & androgen receptor lbd & agonist \\
\hline 4 & 743063 & androgen receptor $\mathrm{lbd}$ & antagonist \\
\hline 5 & 1259387 & androgen receptor with antagonist & agonist \\
\hline 6 & 1259247 & androgen receptor with stimulator & antagonist \\
\hline 7 & 743219 & antioxidant response element & agonist \\
\hline 8 & 743139 & aromatase & antagonist \\
\hline 9 & 743122 & aryl hydrocarbon receptor & agonist \\
\hline 10 & 720516 & ATAD5 & genotoxic inducer \\
\hline 11 & 1347037 & caspase-3/7 in $\mathrm{CHO}-\mathrm{K} 1$ & inducer \\
\hline 12 & 1347034 & caspase-3/7 in HepG2 & inducer \\
\hline 13 & 1224892 & constitutive androstane receptor & agonist \\
\hline 14 & 1224893 & constitutive androstane receptor & antagonist \\
\hline 15 & 1159519 & endoplasmic reticulum stress response & agonist \\
\hline 16 & 743091 & estrogen receptor alpha full & antagonist \\
\hline 17 & 743077 & estrogen receptor alpha lbd & agonist \\
\hline 18 & 743078 & estrogen receptor alpha lbd & antagonist \\
\hline 19 & 1259248 & estrogen receptor alpha with stimulator & antagonist \\
\hline 20 & 1259391 & estrogen receptor alpha with antagonist & agonist \\
\hline 21 & 1259394 & estrogen receptor beta & agonist \\
\hline 22 & 1259396 & estrogen receptor beta & antagonist \\
\hline 23 & 1259404 & estrogen related receptor & agonist \\
\hline 24 & 1259403 & estrogen related receptor & antagonist \\
\hline 25 & 1259402 & estrogen related receptor with $\mathrm{PGC}$ & agonist \\
\hline 26 & 1259401 & estrogen related receptor with PGC & antagonist \\
\hline 27 & 743239 & farnesoid-X-receptor & agonist \\
\hline 28 & 743240 & farnesoid-X-receptor & antagonist \\
\hline 29 & 720719 & glucocorticoid receptor & agonist \\
\hline 30 & 720725 & glucocorticoid receptor & antagonist \\
\hline 31 & 743228 & heat shock response & activator \\
\hline 32 & 1259388 & histone deacetylase & antagonist \\
\hline 33 & 1224896 & histone variant $\mathrm{H} 2 \mathrm{AX}$ & agonist \\
\hline 34 & 1347033 & human pregnane $\mathrm{X}$ receptor & agonist \\
\hline 35 & 1224894 & hypoxia & agonist \\
\hline 36 & 720637 & mitochondrial membrane potential & disruptor \\
\hline 37 & 1159518 & NFkB & agonist \\
\hline 38 & 720552 & p53 & agonist \\
\hline 39 & 743227 & peroxisome proliferator-activated receptor delta & agonist \\
\hline 40 & 743226 & peroxisome proliferator-activated receptor delta & antagonist \\
\hline 41 & 743140 & peroxisome proliferator-activated receptor gamma & agonist \\
\hline 42 & 743199 & peroxisome proliferator-activated receptor gamma & antagonist \\
\hline 43 & 1347036 & progesterone receptor & agonist \\
\hline 44 & 1347031 & progesterone receptor & antagonist \\
\hline 45 & 1159555 & retinoic acid receptor & antagonist \\
\hline 46 & 1159531 & retinoid $\mathrm{X}$ receptor-alpha & agonist \\
\hline 47 & 1159523 & retinoid-related orphan receptor gamma & antagonist \\
\hline 48 & 1259390 & sonic hedgehog signaling & agonist \\
\hline 49 & 1259392 & sonic hedgehog signaling & antagonist \\
\hline 50 & 743067 & thyroid receptor & antagonist \\
\hline 51 & 1224895 & thyroid stimulating hormone receptor & agonist \\
\hline 52 & 1259393 & thyroid stimulating hormone receptor & agonist $\cdot$ antagonist \\
\hline 53 & 1259395 & thyroid stimulating hormone receptor & antagonist \\
\hline 54 & 1347030 & thyrotropin releasing hormone receptor & agonist \\
\hline 55 & 1347038 & thyrotropin releasing hormone receptor & antagonist \\
\hline 56 & 1347035 & transforming growth factor beta & agonist \\
\hline 57 & 1347032 & transforming growth factor beta & antagonist \\
\hline 58 & 743241 & vitamin $\mathrm{D}$ receptor & agonist \\
\hline 59 & 743242 & vitamin D receptor & antagonist \\
\hline
\end{tabular}

AID means assay ID in Tox21/PubChem. 
Tox21 10K compounds library (about 10,000 kinds of compounds, 59 kinds of MIEs )

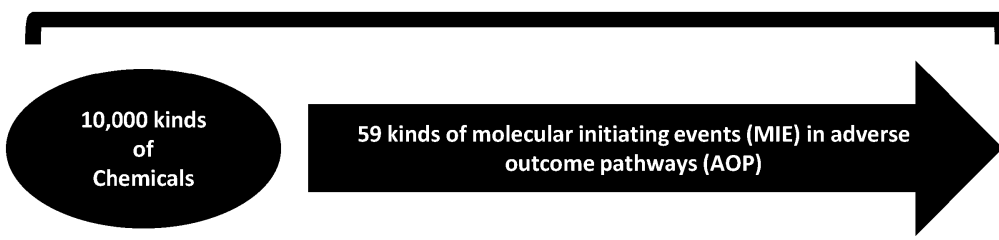

of

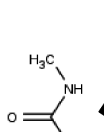

$=$
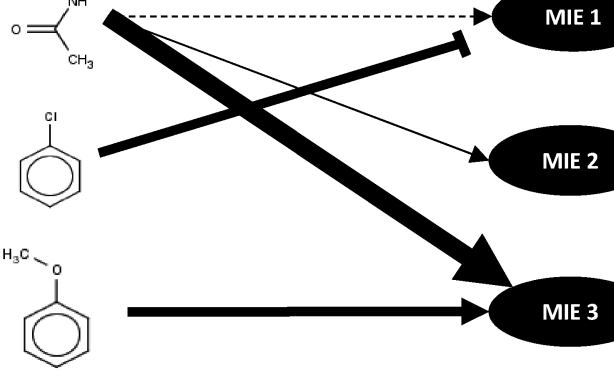

MIE 2

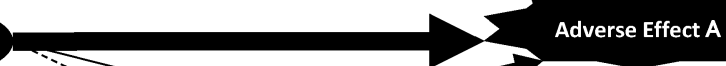

Adverse Effect A
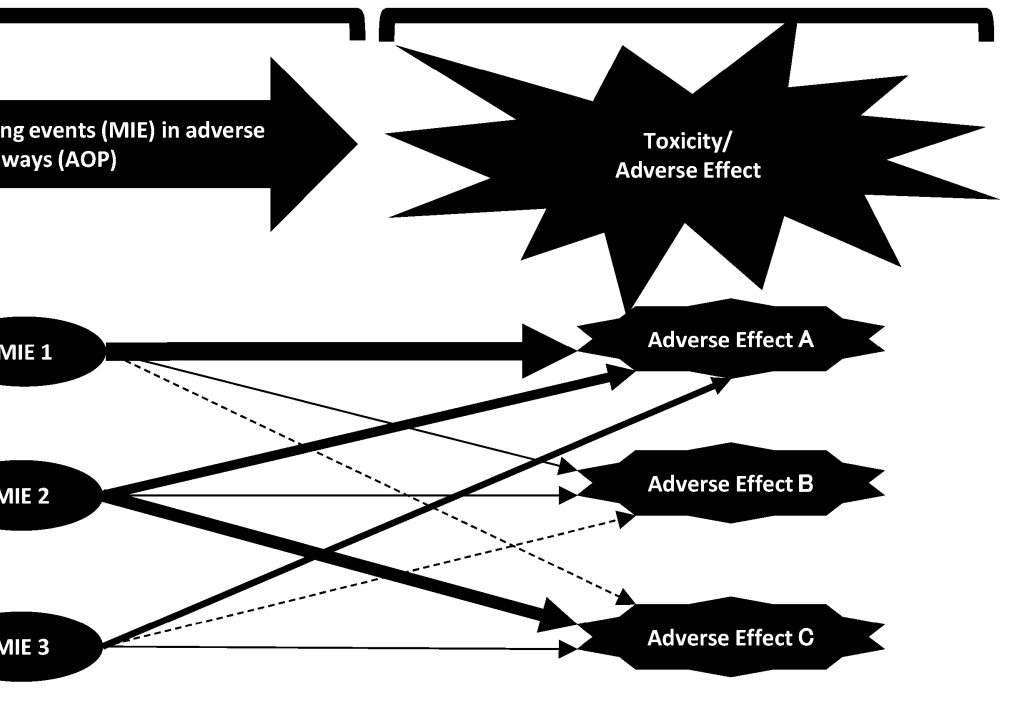
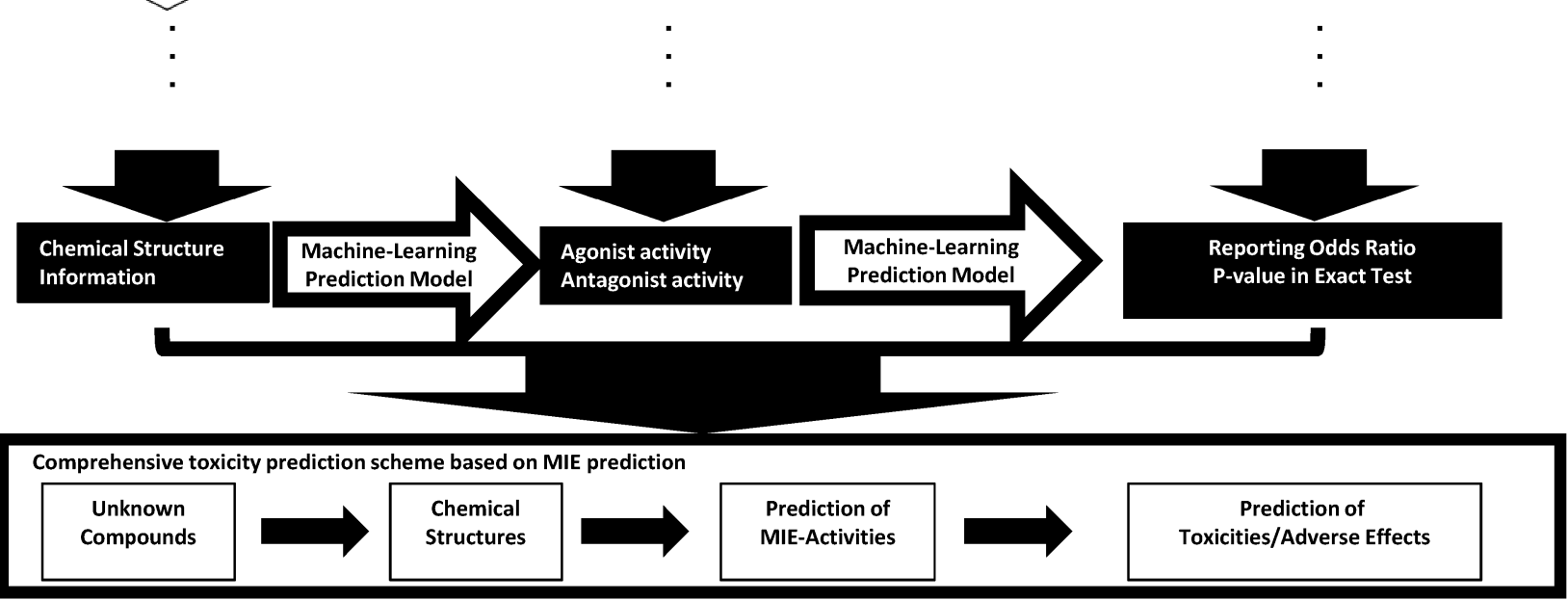

Fig. 2. The Concept of QSAR Prediction for Toxicities/Adverse Effects with Molecular Initiating Events in Adverse Outcome Pathways

対するこの厳密な外部検証における優勝者の予測性 能（AUC）はすべて 0.8 以上であった。ミトコン ドリア膜電位攪乱においては AUC 值が 0.95 と高 度な予測が達成された. ${ }^{2)}$ なお，筆者はランダム フォレストを用い，エストロゲン受容体リガンド結 合部位予測の部において優勝者となつた. ${ }^{17-19)}$ 本コ ンペティションより, 規模の大きなデータと機械学 習を QSAR 予測モデルに適用することによって,

ストレス応答パスウェイのような比較的複雑な生理 現象であっても化学構造情報のみから予測できる可 能性が示された。なお，全課題の半数に関して最良 の予測結果を提出したのは Johannes Kepler University Linz であった. 彼らは優勝者の中で唯一ディー プラーニングを使用したことから話題となった.
ディープラーニングは人工ニューラルネットワーク の一種であるが, 従来法と比較して中間層の重層化 等を特徵とし, 極めて高い予測精度を達成できる新 規な学習法として現在の人工知能ブームを牽引して いる．現在，筆者らもまた独自の手法として分子の 立体構造を画像としてディープラーニングに取り込 む Deep Snap 法が良好な成績を示すことを同コン ペティションのデータを用いて示している. ${ }^{20-22)}$ 今 後, ディープラーニングに関連する様々な手法が発 展し，より高度な QSAR 予測が実現されることが 期待される.

4. 核内受容体・ストレス応答パスウェイに基づ く毒性予測

以上に述べてきたように，完全ではないものの 
QSAR 解析法は種々の生理活性の予測に有用であ る. QSAR を適切に活用することによって，化学 品の規制，医薬品の創薬ステージ，そして臨床的な 応用まで幅広い分野において安全性，動物倫理，経 済性などの面で有益な情報をもたらすことができる と考えられる，一方，今回紹介した解析事例はいず れも機械学習を用いていることから，得られた予測 モデルはヒトの認識の限度を超えて複雑となる。結 果として解釈不能な数式を単に予測結果を得るため に使用することとなる。しかし，説明性の伴わない 予測モデルは毒性学的な知見の創出に寄与し難いば かりでなく，行政，臨床，あるいは共同研究者への 理解を促す必要が生じる様々な場面で使用の制限を 余儀なくされる可能性がある。そこで筆者は，米国 Tox21 プロジェクトが公開している核内受容体・ス トレス応答パスウェイの活性データベース（Table 1）を種々の化学物質の発現する毒性に対する予測 モデルに組み込むことによって，説明性を併せ持つ とともに予測精度の向上を指向した新規なモデルの 概念を提唱した（Fig. 2).

2016 年の日本化学工業協会長期自主研究活動研 究助成金（Long-Range Research Initiative; LRI）課 題「毒性発現経路および化学構造情報を指標とした 薬物および化学物質に起因するヒト有害反応の予測 法の開発」において採択されたこの概念は，国立研 究開発法人日本医療研究開発機構 (Japan Agency for Medical Research and Development; AMED) の 創薬支援推進事業「創薬支援インフォマティクスシ ステム構築」における「肝毒性予測のためのイン フォマティクスシステム構築に関する研究」(グルー プリーダー：山田 弘博士（基盤研））の化学構造 に基づく医薬品の肝毒性予測に採用されている。 さ らに，経済産業省の出資による「毒性関連ビッグ データを用いた人工知能による次世代型安全性予測 手法開発プロジェクト（AI-SHIPS プロジェクト） [プロジェクトリーダー：船津公人教授（東京大 学)］」において構築される化学品の種々毒性予測乇 デルの一部として採用されている。なお，AMED プロジェクトにおいてはヒトの肝毒性をエンドポイ ントとして設定する必要があるが，公共データとし て活用できるヒト肝毒性と紐付いた化合物数は制限 されているのが現状である。そこで，上述した 2016 年 LRI プロジェクトにおいて採択されたアイ
ディアの 1 つである医薬品副作用データベースから エンドポイントを抽出する概念を適用した. ${ }^{18)}$ すな わち，FDA が公開している副作用自発報告デー夕 ベース FDA Adverse Event Reporting System (FAERS) を Japan Pharmaceutical Information Center（JAPIC)が整理した JAPIC AERS を用い, 肝毒性易誘発性化合物を定義するとともにその識別 モデルを構築している．AMED プロジェクトで構 築した肝毒性及び種々核内受容体・ストレス応答パ スウェイ予測モデルは 2019 年度中にポータルサイ トから使用できるように公開を準備中である.

\section{おわりに}

毒性を対象とした QSAR 予測モデルの予測性能 はごの程度信用してよいのか。この誰もが抱く疑問 を解消する目的で，公的なコンペティションの話題 を概説した。 よく吟味された予測モデルであれば, 完全ではないものの予測は可能であることがご理解 頂けたと思う。一方で，公開されている予測モデル が正しいバリデーションを経ているのかは，その信 憑性を左右する最も重要な要因となり得るので注意 が必要である。毒性の QSAR 解析は，実態として の化学物質を必要としない極めてハイスループット 性の高い予測法を提供することができる，予測の限 界を認識しつつ適切に運用することによつて多様な 応用が可能であることは言を俟たない。今後の周辺 分野の進展によって，予測精度の向上とともに適用 分野が拡大していくことを期待したい.

謝辞 本論文の一部で，日本化学工業協会長期 自主研究（LRI）（16_PT01-02），AMED 創薬イン フォマティクスシステム構築 (18nk0101103h0004), 経済産業省 AI-SHIPS プロジェクト（20180314 財 製第 8 号）の支援を受けた内容を紹介しています.

利益相反＼cjkstart開示すべき利益相反はない.

\section{REFERENCES}

1) Case Studies on the Development and Application of in-Silico Techniques for Environmental Hazard and Risk Assessment (CADASTER), Environmental Toxicity Prediction Challenge: $\langle$ http://www.cadaster.eu/node/65.html $\rangle$, cited 26 July, 2019. 
2) National Center for Advancing Translational Sciences, National Institutes of Health, Tox21 Data Challenge 2014: 〈https://tripod.nih. gov/tox 21/challenge/ $>$, cited 26 July, 2019.

3) Hansch C., Fujita T., J. Am. Chem. Soc., 86, 1616-1626 (1964).

4) Cronin M. T. D., Richarz A. N., Schultz T. W., Regul. Toxicol. Pharmacol., 106, 90-104 (2019).

5) Heo S., Safder U., Yoo C., Environ. Pollut., 253, 29-38 (2019).

6) Kar S., Roy K., Leszczynski J., Methods Mol. Biol., 1800, 395-443 (2018).

7) Adhikari C., Mishra B. K., Curr. Comput. Aided Drug Des., 14, 7-28 (2018).

8) Furuhama A., Toida T., Nishikawa N., Aoki Y., Yoshioka Y., Shiraishi H., SAR QSAR Environ. Res., 21, 403-413 (2010).

9) Kaiser K. L., Niculescu S. P., Schultz T. W., SAR QSAR Environ. Res., 13, 57-67 (2002) .

10) Castillo-Garit J. A., Abad C., Casañola-Martin G. M., Barigye S. J., Torrens F., Torreblanca A., Curr. Pharm. Des., 22, 5085-5094 (2016).

11) Case Studies on the Development and Application of in-Silico Techniques for Environmental Hazard and Risk Assessment (CADASTER) : $\langle$ http://www.cadaster.eu/node/4.html $\rangle$, cited
26 July, 2019.

12) National Center for Advancing Translational Sciences (NCATS): 〈https://ncats.nih.gov/〉, cited 26 July, 2019.

13) Gohlke J. M., Thomas R., Zhang Y., Rosenstein M. C., Davis A. P., Murphy C., Becker K. G., Mattingly C. J., Portier C. J., BMC Syst. Biol., 3, 46 (2009).

14) Mayr A., Klambauer G., Unterthiner T., Front. Environ. Sci., 3, 1-13 (2016).

15) Huang R., Xia M., Front. Environ. Sci., 25, 1-3 (2017).

16) Uesawa Y., Front. Environ. Sci., 15, 1-6 (2016).

17) Uesawa Y., Farumashia, 51, 952-956 (2015).

18) Uesawa Y., Yakugaku Zasshi, 138, 185-190 (2018).

19) National Center for Advancing Translational Sciences (NCATS), National Institutes of Health, NCATS Announces Tox21 Data Challenge Winners: 〈https://ncats.nih.gov/ news / releases / 2015 / tox21-challenge-2014winners $\rangle$, cited 26 July, 2019.

20) Uesawa Y., Bioorg. Med. Chem. Lett., 28, 3400-3403 (2018).

21) Uesawa Y., CICSJ Bull., 36, 51-54 (2018).

22) Matsuzaka Y., Uesawa Y., Front. Bioeng. Biotechnol., 7, 65 (2019). 